\title{
The Structure and Main Elements of Disaster Management System of the Hungarian Defence Forces, with Special Regard to the Development of International Cooperation
}

\author{
Tamás BEREK, László FÖLDI, ${ }^{2}$ József PADÁNYI³
}

\begin{abstract}
The use of military forces in disaster relief activities is indispensable. It is a human and technical resource that can carry out special tasks quickly and professionally. One of the negative consequences of the global climate change is the increasing number and intensity of natural disasters, where the role of the military is more and more appreciated. For Hungary, as a small country and a member of the NATO, it is important to have a compact but capable military, which is able to work in a wide range of different scenarios of crisis management from peace support to disaster operations, especially in a multinational environment. This study introduces the disaster management capabilities of the Hungarian Defence Forces, focusing on the existing and planned international cooperations.
\end{abstract}

Keywords: Hungarian Defence Forces, climate change, disaster management, use of military force.

\section{Introduction}

There are plenty of hazard sources in Hungary which can cause disasters. Some of them immediately, and others by activating a series of secondary hazards. We can categorise them from several points of view. One way of grouping them is the following: [1: 118]

Ph.D., associate professor, Department of Operations and Support, Faculty of Military Science and Officer Training, National University of Public Service; e-mail: tamas.berek@uni-nke.hu, ORCID: https://orcid. org/0000-0001-8358-6139

2 Ph.D., professor, Department of Operations and Support, Faculty of Military Science and Officer Training, National University of Public Service; e-mail foldi.laszlo@uni-nke.hu, ORCID: https://orcid.org/0000-00017575-7188

3 DSc, professor, Department of Military Strategy, Faculty of Military Science and Officer Training, National University of Public Service; e-mail padanyi.jozsef@uni-nke.hu; ORCID: https://orcid.org/0000-0001-6665-8444 
T. BEREK, L. FÖLDI, J.PADÁNYI: The Structure and Main Elements of Disaster Management...

Hazards of civilisational origin:

- nuclear hazards (e.g. domestic nuclear energy installations, transportation of nuclear or radiological materials and consequences of nuclear accidents abroad);

- hazards of production, storage and use of dangerous goods (e.g. dangerous industrial infrastructure and hazardous waste);

- hazards of transportation of dangerous goods (on roads, railways, rivers and seas, by air, or direct or indirect effects of space technology).

Hazards of natural origin:

- hydrological hazards (floods, inland waters or droughts);

- geological hazards (earthquakes, different soil and rock movements);

- meteorological hazards (from extreme weather situations).

Hazards of human or ecological origin

- diseases (epidemic or pandemic situations);

- migration;

- proliferation of weapons of mass destruction and their delivery means;

- terrorism;

- ecological disasters (e.g. animal epidemics, forest- and wildfires)

- Practically, there is no such part of Hungary where hazards would not exist. Moreover, there are many areas where more than just one type of disasters can happen. Good examples are the industrial territories, where different types of dangerous marerials are in use and at the same time the local population is dense. [2] The chance for disasters is further increasing due to more and more extreme weather events originating from global climate change.

\section{Legal Background}

In Hungary, the constitution guarantees the right of citizens to the safety of their life and wealth. From this, it is obvious that any organisations which can take part in disaster relief activities have the obligation to play an active role in it. It is true for the military, too. The history of military forces prove that every country needs this human and technical resource in disaster prevention and relief. On the one hand, the help from the military does matter in cases when local disaster management forces cannot handle the situation because of its severity. On the other hand, military involvement can be essential during disaster situtions when special or customised capabilities and tools are needed to solve unique problems.

In Hungary, the Act 128/2011. on the protection against disasters and its related acts, together with some special departmental regulations (including those referring to the Hungarian Defence Forces [in the following: HDF]) essentially regulates domestic disaster management tasks and responsibilities and creates the legal base of the so-called “national disaster management system”. At the same time, continuous development of legal regulations concerning disaster prevention, relief and restoration, fine tuning of tasks and responsibilities, organisational and command structures are essential. 
T. BEREK, L. FÖLDI, J.PADÁNYI: The Structure and Main Elements of Disaster Management...

Concerning our military, disaster management tasks and responsibilities of the HDF are formulated in the National Defence Departmental Disaster Management Plan. [3]

\section{Cooperation Issues}

The complexity of disaster situations and the number of involved relief organisations demand significant cooperation on both command and execution levels. While planning and organisations are the main areas of cooperation in the phase of disaster prevention, efficient phasing of the on-site activities during disaster relief is the most important objective. Though particular tasks of cooperation can vary in different disaster scenarios, there are some basic principles. One of them is that it is practical to organise and maintain cooperation on the same level between the stakeholders. Another significant feature of cooperation is the utilisation of mutual benefits in prevention or relief of disasters. This requires continuous and timely exchange of information and synchronisation of tasks in time and space to avoid parallel (and thus redundant) work of partners.

Cooperation can be successful if it works proactively, that is, stakeholders should specify its purpose, location, time, involved forces, tasks, order of subordination and way of command in time, at the phase of prevention. It must be clear that cooperation is not a standalone, separate task, but a comprehensive approach for the whole defence. It is an integral part of the commandeering of troops because this can only be successful with joint, aligned actions of all stakeholders in disaster management.

\section{Opportunities of the HDF}

It is obvious that the primary tasks of our military force are the protection of the country's independence and compliance with alliance obligations. The constitution of Hungary clearly states that the Hungarian military takes part in disaster protection activities as a contributor, in other words, the HDF is a part of the national disaster management system. This is not an extraordinary obligation, almost every country uses this kind of human and technical resources. Of course, preparation for this task in organized manner is controlled by the regulations of the National Defence Departmental Disaster Management Plan. [4]

The Defence Departmental Disaster Management System (in the following: DDDMS) is a decisive element of the national disaster management system, it describes the details for planning, organisation, command and execution of the military's disaster management tasks. It contains all functions that the military provides during disasters. This continously improving document lists all the temporarily generated, designated subunits which, based on the HDF's present capabilities, have the task to contribute in disaster protection inside (or, if it is necessary, outside) our national borders.

It is important to emphasise that there are many other tasks among the basic duties, so not the participation in disaster management is the primary function of the HDF. In a disaster situation, in a given time and place they take part in disaster relief operations, that is why these tasks are called "temporary services". 
When situation is declared as “disaster danger”, these forces and equipment will be on standby. This means that they are prepared and also preparing their subunits and equipment to be capable to move onto the disaster site and start the assigned defence activities immediately in case of need. The military subunits involved in the DDDMS take part in thematic trainings and exercises regularly.

Let us see what kind of military units the DDDMS contains and what are their capabilities. [5: 4] We did not narrow down our investigation only to flood protection, because the majority of the subunits are multi-purpose, they can be alarmed and used in different types of disasters. This can be advantageous, as we know that disaster situations can be sometimes very complex. There is often not just one type of danger on the site, mainly because of the so-called "domino effect". This means that a disaster can cause a series of other hazards (e.g. at Fukushima on $11^{\text {th }}$ March 2011 the primary disaster was an earthquake, that raised a tsunami which caused a serious nuclear accident).

- CBRN $N^{4}$ Area Control Centre (CBRN ACC) and CBRN Zone Control Centre (CBRN ZCC): They are to be established at national commands. CBRN ACC has to observe the CBRN Area of Observation, the borders of which are the national borders. In peacetime, the Area of Observation may be sub-divided into Zones of Observation in case of a natural or humanitarian disaster, and HDF Command appoints one or more CBRN ZCCs to assume responsibilities. Their main tasks include:

- Information Fusion: The gathering of the information by sensors, observers and other CIS, which detect, identify and monitor CBRN incidents. The fusion of this information is expected to provide accurate and timely picture of CBRN incidents within the battle space.

- Analysis and Assessment: The display, modelling and simulation of these CBRN incidents for the prediction of consequences for CBRN Defence. The use of these coclusions for the adoption of appropriate physical protection, risk assessment, hazard management, and medical countermeasures and support.

- Reporting: The timely exchange of CBRN information/output between National CIS, National Control Centres (static and deployed) and NATO CIS in order to warn and report about CBRN incidents and their consequences.

- Filtering: The filtering of information should result in processing and display of CBRN Defence situation that they have to be appropriate to the users at both tactical, operational and strategic levels. [6]

- CBRN Survey Group: Its tasks are reconnaissance of chemically or radiologically contaminated areas on land, checkup of chemical or radiological contamination of personnel, objects, materials and equipment, and proposals to determine methods of eliminating the consequences of the disaster.

- CBRN Decontamination Group: It has the task to perform thorough/operational personnel and material decontamination missions - including dress and individual equipment, vehicles, sensitive optical/electrical material -, and conduct fixed-site and terrain/road decontamination missions.

4 CBRN: This abbreviation stands for Chemical, Biological, Radiological and Nuclear (previously: NBC) issues in armed forces. Generally, it means the defence against Weapons of Mass Destruction (WMD). 
T. BEREK, L. FÖLDI, J.PADÁNYI: The Structure and Main Elements of Disaster Management...

- Nuclear Early Warning System (NEWS) Support Group: Its mission is to install mobil NEWS subsystems in directions of interest for increasing station density and/or support critical objects.

- SCUBA Diving Group: Its missions are:

- Reconnaissance, strengthening and insulation of dams from the direction of the water in case of floods.

- Underwater survey of damaged flood protection structures.

- Participation in removal of damaged flood protection structures (demolition tasks).

- Participation in life and wealth rescue operations during water transportation accidents.

- Biological Diagnostics Group: Its mission is to analyse biological samples collected and sent from the site to detect possible causative agents. It includes a Mobile Biological Laboratory Complex with complete staff and equipment.

- Lifting Machinery Group: It has the mission to load and unload transport vehicles with the necessary flood protection materials (sandbag, gabion, straw bale, etc). It also participates after earthquakes in ruin removal operations and personnel rescue missions when people are trapped under ruins, restoration of public utilities and wrecking works. It provides assistance in loading and unloading military transport railway trains and lifting heavy objects and materials.

- Epidemiologic Group: Its task is the epidemiologist work on site under the supervision of the military chief epidemic officer. On-site control and survey, necessary countermeasures and sample taking in case of need.

- Medical Group: Its main task is to provide primary life-saving and professional onsite medical first aid.

- Electric Power and Lighting Supply Group: Its mission is to support disaster relief forces providing electric power and lighting.

- HAVARIA Laboratory: Its mission is to recon chemical or radiological contamination in case of industrial disasters, to measure the range of contamination and its borders, and qualitative and quantitative analysis of released hazardous chemical or radiological materials. Its experts give proposals to determine complex methods of eliminating the consequences of the disaster.

- Light Geoworks Machinery and Ruin Removal Group: Its task is to perform different soil mobilisation works.

- Delivery Group: Its main task is to transport personnel.

- Light Water Transporter/Medic and Waterways, Water Area Locking Support Group: Its mission is to perform and assist in transportation and rescue tasks on water.

- Air Support Group: Its mission is to perform air reconnaissance and survey of disaster sites, rapid transportation of the wounded to hospital, support closed or occluded areas with food and medication, airborne search and rescue from occluded or life threatening sites, dam strengthening from the air and participation in firefighting.

- Airborne Radiological Reconnaissance Group: It has the mission of fast reconnaissance of radiologically contaminated area in case of nuclear disaster, including reconnaissance of large contaminated areas (with the effectiveness of ca. $300 \mathrm{~km}^{2} / \mathrm{h}$ ), searching for separated radioactive sources and limited identification of radioactive isotopes. 
T. BEREK, L. FÖLDI, J.PADÁNYI: The Structure and Main Elements of Disaster Management...

- Mobile Medical Group: Its mission is to give medical attendance with their professional equipment to the wounded and make them transportable from the disaster site.

- Heavy Geoworks Machinery and Ruin Removal Group: Its task is to perform different soil mobilisation works.

- Heavy Amphibious Rescue Group: Its mission is to carry out transportation and rescue on heavy terrain and on water during floods.

- Vaccination Group: Its task is the immunisation of the designated personnel with its equipment and giving certificate of inoculation under the supervision of the military chief epidemic officer.

- Medical Support Group, Hospital Bed Capacity: Its task is to provide special medical care on a detached 100-bed hospital capacity.

- Psychologist Advice Group: Its mission is to provide psychological support to the military personnel involved in disaster relief and prevention against Post Traumatic Stress Disorder (PTSD).

- Military Police Group: Its mission is to provide police support and convoy escort to and from the accident site in case of the use of a larger military force.

- Demolition Group: Its mission is to carry out demolition works (in ice, soil, objects and buildings) and cutting with explosives.

- Radiation Health Protection Laboratory: Its mission is to carry out radio-medical control, give proposals to decision-makings and to the necessary countermeasures.

- Personnel Transport Group: It consists of five buses with drivers.

- Transport Towing Group: Its mission is to transport materials and valuables and tow damaged vehicles.

- Land Area and Road Closing Support Group: Its task is to close or secure areas or roads on disaster sites, extremely important for defence and unobstructed movement.

- Field Support Group: Its task is to give full logistic support on field for 200 250 persons involved in disaster relief (meal, bed, electricity).

- Winter Emergency Response And Rescue Group: Its mission is to rescue lives and valuables in case of extreme weather emergencies during wintertime, including rescue of public transport vehicles and cars with passengers stucked in snow, cleaning of important road crossings, transportation of wounded or sick persons to hospital and support of closed or occluded areas with food and medication.

- Manual Defence and Wrecking Working Group: Its task is to strengthen dams and remove ruins and wreckages with hand tools, fill-up of soil and sandbags and their hand delivery, participation in lookout service, rescue of lives and valuables under the supervision of the on-site commander. It includes 50 persons and 3-4 all-terrain vehicles. The group is capable to fill sandbags with a performance of 800 pieces/hour and deliver sandbags within 5 metres to vehicles with a performance of 2500 pieces/hour.

- Water Transportation Group: Its mission is to support the strengthening and insulation of dams from the direction of the water in case of floods, delivery of materials, support of rescue operations on areas flooded by water, and the operation of cargo ferry.

- Water Purification Group: Its mission includes water retrieval, water purification and to provide both the disaster relief forces and the population with drinking water. 
T. BEREK, L. FÖLDI, J.PADÁNYI: The Structure and Main Elements of Disaster Management...

- Tracked Winter Emergency Response and Rescue Group: Its mission is to rescue lives and valuables in case of extreme weather emergencies during wintertime in areas impassable for wheeled vehicles. Its tasks include rescue of public transport vehicles and cars with passengers stucked in snow, cleaning of important road crossings, transportation of wounded or sick persons to hospital and support of closed or occluded areas with food and medication.

- CIMIC and PSYOPS Group: Its main task is to inform both the disaster relief forces and the population about the current disaster situation. It includes seven persons (four officers, three NCOs) and three MG G270 cross-country vehicles (one of them is the PSYOPS multimedia car). The group is capable to make CIMIC databases and analyses on their area of responsibility, and to provide and hand over their connection network and database to the experts of on-site disaster relief subunits.

- Non-conventional Transport and Escort Group: Its mission is to transport special personnel and technical equipment, escort convoys and oversized vehicles.

- Airborne Radiological Reconnaissance Patrol: Its mission is to carry out airborne radiological reconnaissance with its regular equipment.

- CBRN Casualties Decontamination Group: Its task is to decontaminate and attend civil and military casualties rescued from territories contaminated with hazardous chemicals, radioactive or biological agents.

- Salvager and Transloader Group: Its task is to transload liquid hazardous chemicals on site from damaged containers to elastic tanks.

- Water Sucking and Pumping Group: Its mission is to participate in cleaning terrain elements covered by water (roads, ditches, tunnels, buildings, houses) by sucking and pumping water.

We can see that military troops can provide such a large-scale assistance during disaster relief activities as no other rescue organisations in our country. They can operate with full logistic support capability, which means that involved military forces can supply themselves, so their application does not generate any need of subsequent capacities. Rapid mobilisation, special equipment, skilled personnel together with full logistic support capabilities increase their value even further.

\section{The “Tisza” Multinational Engineer Battalion}

The tasks of the joint Hungarian-Romanian-Slovakian-Ukrainian subunits of the "Tisza" battalion are:

- prevention of floods or other natural disasters, ecological catastrophes on the catchment area of River Tisza;

- direct intervention to help the local population;

- taking part in disaster relief operations (damage reduction and/or elimination).

The staff of this temporary military organisation consisting of four engineer companies holds exercises every year. The battalion and its equipment is specially organised and shaped in order that in case of floods the capabilities effectively intervene, save lives and 
T. BEREK, L. FÖLDI, J.PADÁNYI: The Structure and Main Elements of Disaster Management...

strengthen damaged dams. Every time, the commander comes from the effected country where the exercise is held or the disaster relief works are done. [7]

The Hungarian company of the "Tisza” battalion consists of 154 persons. Its decisive subunits are:

- Sapper Platoon: It is capable to provide reconnaissance data or refine existing data, operate cargo ferry or rescue lives and valuables with its assault-boats. Its water purification section is capable to support both the forces involved in the disaster relief and the affected local population with potable water in case of the damage of public utility services. With their bagging equipment the potable water can be packed and dispensed without any risk of infection.

- Assault Water Crossing Platoon: It is capable to rescue 840 persons or 60 tons of materials at a time or transport 1200 sandbags to the defence site.

- Pontoon Platoon: Its mission is to rescue and transport heavy materials and technical equipment on water.

Additional subunits coming from other nations' armed forces into “Tisza” battalion are the following:

- Slovakian Engineer Company: It has two sapper platoons, a pontoon platoon, a road building platoon and a logistics platoon with 150 soldiers.

- Romanian Engineer Company: It consists of a bridge building platoon, a pontoon platoon, an assault water crossing platoon, a road building platoon and a logistics platoon with 168 soldiers.

- Ukrainian Engineer Company: It has an engineer platoon, a bridge building platoon, a road building platoon and a logistics platoon with 163 soldiers. [8]

\section{Developments}

Capability development of the Hungarian Defence Forces is continuous even in the field of disaster management. An important phase of this procedure is the latest procurement of disaster relief equipment carried out with an almost 6 million EUR financial support from the European Union.

Thanks to the support of the European Union Cohesion Fund and the Hungarian government as co-financer, this development will help the Hungarian Defence Forces to provide assistance in disaster management on higher standards in prevention and elimination of natural disasters including floods. The project will be realised with a total budget of 2.215 billion HUF (6.5 million EUR) with a 100\% of EU support of 2.005 billion HUF (5.9 million EUR). With this investment, the Hungarian Defence Forces carries out a large-scale equipment modernisation needed for its participation in disaster management activities, mainly in flood protection.

With this development, the Hungarian Defence Forces will be able to maintain all of its previous contribution capabilities in disaster management and to increase their performance. Besides this, the Hungarian Defence Forces contributes to the development of the capabilities of the National Disaster Management System with its enriched performances. [9: 7] The modernisation of its command and control system and the infocommunication capabilities 
of its intervening subunits will make the field cooperation with other organisations' units easier and better.

Development of informatics and office technical equipment, procurements of digital radio transmitters and portable field chemical identification devices will be carried out in the project. Besides the individual protective gears used in flood protection, high delivery pumps, field camp lighting systems, dinghies and outboard motors will be put into service. Renewal of old amphibious vehicles used in flood protection, suitable for the rescue of the population, will be carried out to improve their capatilities of food and drinking water supply. In addition, modification and modernisation of the fuel supply system and capability improvement of field tent quartering are to be realised.

Procurement of technical devices includes the following:

- high delivery gasoline-powered portable slop pump and high delivery gasolinepowered portable drinking water pump;

- field camp lighting system mounted on truck trailer;

- industrial diving suit;

- light diving suit;

- dinghy with outboard engine;

- outboard engine (four strokes engines with 30 BHP);

- average performance universal engineer geoworks machine;

- life vest and life-ring.

In addition to these, renewal of eight PTS-M (PTS stands for Plavayushchij Transportyer - Sryednyj = medium amphibious transport vehicle) tracked amphibious vehicles has been started, that can be involved not only in flood protection but also in extreme winter weather emergency relief activities. The newly procured heavy transport trailer is perfectly suitable to their transport to the disaster site. Another result of the development is the renewal of a fuel transport truck and eight trailers with one cubic meter of water tanks.

\section{Conclusions}

The described system has been continuously developed for years, but it is obvious that there are still some areas that should be improved. Monitoring of international results is important to gain opportunity to implement new solutions, for example in the command and control system, in special equipment, or training and exercise.

One thing is for sure: protection against disasters cannot be privatised either by organisational or individual ambitions. This task can be successfully and effectively solved only in cooperation, systematically using all of the resources that we altogether have, and utilising existing synergies.

We can be sure that hazards of serious floods will increase due to the consequences of global climate change. Not the yearly amount of precipitation will be higher, but the precipitation pattern is changing, including more and more extremities recently. Longer dry periods are predicted followed by shorter but more intensive rainy periods, often with extreme rainstorms and thunder showers. Meteorological experts forewarn us of increasing chance of supercell 
T. BEREK, L. FÖLDI, J.PADÁNYI: The Structure and Main Elements of Disaster Management...

formation. [10] All of these can cause higher flood peaks on any of our rivers. We cannot raise the altitude of our dams higher and higher every year, so the risk of floods will increase and useful capabilities of intervening relief forces will become more valuable.

\section{References}

[1] SCHWEICKHARDT, G.: A katasztrófavédelem rendszere. [System of disaster management.] Budapest, Dialóg Campus, 2018. https://akfi-dl.uni-nke.hu/pdf_kiadvanyok/ web_PDF_EKM_A_katasztrofavedelem_rendszere.pdf (Dowloaded: 19.02.2020)

[2] HORNYACSEK J. - KESZELY L.: A katonai erők, képességek alkalmazása katasztrófák esetén. [Application of military forces and capabilities during disasters.]

Hadmérnök, 82 (2013), 191-209. www.hadmernok.hu/132_18_hornyacsekj_kl.pdf (Dowloaded: 25.01.2020)

[3] 62/2014. (IX. 26.) HM utasítás a Honvédelmi Katasztrófavédelmi Rendszer Szervezeti és Múködési Szabályzatának kiadásáról. [Decree of the Minister of Defence No. 62. on $26^{\text {th }}$ September, 2014 about the Regulation of Operation of the Defense Departmental Disaster Management System.] https://net.jogtar.hu/jogszabaly?docid=A14U0062. HM\&txtreferer=00000003.TXT (Dowloaded: 24.01.2020)

[4] Megújul a Honvédelmi Katasztrófavédelmi Rendszer eszközparkja. [Equipment of the Defence Departmental Disaster Management System is renewing.] Honvedelem.hu, 2016. https://honvedelem.hu/cikk/59555_megujul_a_honvedelmi_katasztrofavedelmi_ rendszer_eszkozparkja (Dowloaded: 26.01.2020)

[5] CSURGAI, J.: The New Disaster Management System of the Hungarian Defense Forces in the Light of Climate Change with Special Emphasis on Nuclear Accidents. In KRULÍK, O. - PADÁNYI, J. - RATHAUSKÝ, Z. - ŠESTÁK, B. eds.: Climate Change and its Security Impacts: Proceedings from the International Scientific Conference. $18^{\text {th }}$ and $19^{\text {th }}$ September 2019. Prague, Policejní Akademie České Republiky v Praze.

[6] ATP-45(D) - Warning and Reporting and Hazard Prediction of Chemical, Biological, Radiological and Nuclear Incidents (Reference Manual). NATO NSO STANAG 2103.

[7] PADÁNYI, J. - FÖLDI, L.: Tasks and Experiences of the Hungarian Defence Forces in Crisis Management. Bilten Slovenske Vojske (Contemporary Military Challenges), 171 (2015), 29-46.

[8] SOMLAI-KISS A.: A TISZA Többnemzeti Múszaki Zászlóalj bemutatása különös tekintettel az árvízvédelmi szerepére. [Introduction of the TISZA Multinational Engineering Battalion with special emphasis on its role in flood protection.] Müszaki Katonai Közlöny, 21 Special editions (2011), 992-1006.

[9] PADÁNYI, J. - FÖLDI, L.: Military Technical Developments in Hungary in the Frame of ZRINYI 2026 Program. In KŘIVÁNEK, V. ed.: 2019. International Conference on Military Technologies (ICMT). Brno, IEEE, 2019. 1-7. DOI: https://doi.org/10.1109/ miltechs.2019.8870061

[10] HALÁSZ, L. - FÖLDI, L.: New tendencies in global climate change and their effects on the climate of Hungary. Hadmérnök, 141 (2019), 99-107. www.hadmernok.hu/191_09_halasz. pdf (Dowloaded: 18.02.2020) 